\title{
Single breath transfer factor for carbon monoxide in an asymptomatic population of never smokers
}

Amund Gulsvik, Per Bakke, Sjur Humerfelt, Ernst Omenaas, Tor Tosteson, Scott T Weiss, Frank E Speizer

\begin{abstract}
Background Data on reference values of transfer factor variables in general populations of asymptomatic never smokers are limited. The aim of this study was to examine the relation between test variables and age, height, haemoglobin concentration and carboxyhaemoglobin concentration.

Methods Measurements of single breath transfer factor for carbon monoxide (TLCO) were obtained for a randomly selected sample of never smokers in north western Europe who were 18-73 years old and had no respiratory symptoms or disorders. Two recordings of TLCo with a ratio of inspiratory vital capacity to forced vital capacity of $>0.09$ were obtained by standardised techniques for 304 subjects.
\end{abstract}

Results The measurement errors expressed as a percentage of the common mean value of TLCO, volume adjusted TLCO (KCO), and alveolar volume (VA) were $4.5 \%, 4 \cdot 2 \%$, and $2 \cdot 4 \%$ respectively. Multiple linear regressions showed sex specific effects of height and age on TLCO, and, in addition, of haemoglobin and carboxyhaemoglobin concentrations on Kco. VA was associated with height but not with age. The 5 th and 95 th centiles for TLCO and KCO in men and women were between $78 \%$ and $82 \%$ and between $120 \%$ and $127 \%$, respectively, of predicted values when age and height were taken into account.

Conclusion Reference equations and normal values for transfer test variables in a large healthy population of never smokers are described in relation to age, height, and haemoglobin concentrations. To our knowledge, this is the first report of an association between carboxyhaemoglobin concentrations and $K C O$ in a population of never smoking men and women.

Single breath carbon monoxide transfer factor (TLCO) is a simple, non-invasive measure of gas exchange that has been used routinely in clinical respiratory laboratories for more than 35 years. ${ }^{1}$ Low values may suggest emphysema ${ }^{2}$ or fibrosing alveolitis, ${ }^{3}$ whereas high values occur in polycythaemia ${ }^{4}$ and pulmonary haemorrhage.
The test, in which an inert tracer gas such as helium is used, also yields a measurement of alveolar volume (VA). TLco may also be expressed per litre of lung volume (Kco). Measured values are usually assessed in relation to predicted values from equations that take height and age into account. Such data for healthy non-smokers are available but limited. ${ }^{6-12}$ The methods of selection and the size and characteristics of the populations assessed have varied among studies, as have details of test methodology. Guidelines for measurements of TLCO have been published by the Working Party of the European Community for Coal and Steel ${ }^{13}$ and the American Thoracic Society. ${ }^{14} 15$

The present study of TLCo in never smokers without occupational exposure to asbestos or quartz and without respiratory symptoms followed the guidelines of the working party with some minor deviations. The survey investigated the acceptability of TLCo measurement in a general population, the precision of the Tico variables measured, and the relation between transfer test variables and age, height, haemoglobin concentration, and percentage of carboxyhaemoglobin in never smoking, asymptomatic adults randomly selected from the general population of the south western coast of Norway. Reference equations and lower limits of normal values were derived for both sexes, and regression equations were compared with other prediction equations.

\section{Methods}

POPULATION STUDIED

A standardised questionnaire was sent to 4992 people randomly selected from the 267304 inhabitants aged 15-70 years in the county of Hordaland in September to December 1985. The county is on the south western coast of Norway and consists of 34 municipalities. Bergen is the only urban municipality in the county, and contains almost half of the county's population. The questionnaire was a modified Norwegian language version of a British Medical Research Council questionnaire and included information on respiratory disorders, smoking habits, and occupational exposure to asbestos and quartz. In all, 4469 people (90\%) responded.

Respondents living in Bergen or in one of 11 surrounding municipalities $(\mathrm{n}=3370)$ were divided into groups based on the information obtained from the questionnaire. The
$S$ T Weiss

Reprint requests to:

Dr Gulsvik

Accepted 19 September 1991 
"healthy" stratum included 737 people who had never smoked, had never been occupationally exposed to asbestos or quartz, and had neither a history of asthma or emphysema nor respiratory symptoms (that is, cough in the morning, phlegm, chest illnesses of three weeks' duration or more during the past two years, more breathlessness than subjects of the same age walking uphill, and occasional wheezing). Of these 737 subjects, $663(90 \%)$ were randomly selected and invited to attend the chest clinic at the Department of Thoracic Medicine, University of Bergen. Altogether, 540 subjects ( $81 \%$ of those invited) attended the examination. The survey started in April 1987 and ended in August 1988.

\section{TLCO MEASUREMENTS}

The Gould 2100 automated system (SensorMedics BV, Bilthoven, Netherlands) consisted of two mass flow anemometers, a demand valve connected to a tank of test gas, and a solenoid valve connected to a 0.751 alveolar sampling bag. The separated heated wire anemometers were used to measure inspiratory and expiratory volumes; the performance of these instruments was judged as acceptable in dynamic waveform testing. ${ }^{16} \mathrm{Gas}$ analyses were performed with a carbon monoxide electrochemical analyser (National Draeger, Pittsburgh, Pennsylvania, United States) and a thermal conductivity helium analyser (Gow-Mac, Madison, New Jersey, United States). The system, including valves and measurements of breath holding time, is controlled by a microprocessor (Gould IPS OBO1-OH).

The breath holding time was preset to 10 seconds and the washout volume to 0.751 . The sample bag $(0.75 \mathrm{l})$ shuts off at a pressure of $13 \mathrm{~cm} \mathrm{H}_{2} \mathrm{O}$. The dead space of the sample bag was $6.25 \mathrm{ml}$. A chemical absorber was used for carbon monoxide (Soda-sorb, Dewey and Almy, Lexington, Massachusetts, United States) and for water vapour calcium sulphate (Drierte, WA Hammond Company, Xenia, Ohio, United States). The 10 test gas bottles used during the survey contained carbon monoxide at concentrations varying from $0.286 \%$ to $0.301 \%$, helium concentrations from $9.8 \%$ to $10.3 \%$, oxygen concentrations from $20.9 \%$ to $21.9 \%$, and a balance of nitrogen.

Before the test was performed each subject was instructed in all the required manoeuvres. Points that were emphasised included the importance of giving a sign when at maximal exhalation (residual volume), inhaling the test gas rapidly to vital capacity, continuing to hold the breath (assisted by the valve system) for 10 seconds, and exhaling a volume of at least 2.01 rapidly. Two satisfactory tests were carried out with at least four minutes between the two tests.

The helium and carbon monoxide analysers were calibrated with room air and the diffusion test gas. Gas concentration values were allowed to deviate by only $\pm 0 \cdot 1 \%$ between meters. The spirometer was calibrated automatically with a $2 \cdot 11$ motor driven syringe before each examination. The volume calibration was verified each day with a 31 Gould Model M-20 calibrating syringe, with emptying times varying from $0.5 \mathrm{~s}$ to $6 \mathrm{~s}$. Furthermore, Tlco, Kco, VA, and inspiratory vital capacity (IVC) were measured randomly in one of two people of the survey team on each day of the study to ensure that the system gave repeatable results and that the instrument did not drift during the 235 examination days of the survey. Observations made during the first 18 days were excluded when a leak was discovered in the sample bag.

The test was performed with the subject in a sitting position and breathing normally through the mouthpiece. The screen displayed a dashed vertical time indicator and a dotted horizontal line at $\mathbf{0 . 9 5}$ of the subject's largest stored forced vital capacity (FVC) ${ }^{17}$ In each trial the laboratory technician tried to obtain an IVC for each subject of at least 0.95 of the maximum FVC (maxFVC). When the breath holding time marked on the screen was achieved the subject was instructed to exhale rapidly. Trials with slow inspiration, cough, or Valsalva manoeurres, and stepwise or hesitating expiration were excluded. The contents of the sample bag were pumped automatically through the helium and carbon monoxide analyser. The water absorber preceded the carbon dioxide absorber in the gas flow. The breath holding time was measured by the method of Jones and Meade, ${ }^{18}$ which includes 0.5 of the sample collection time minus 0.3 of the inspiration time. The basic formula recommended by the American Thoracic Society ${ }^{14}$ was applied to the calculation of TLCO. VA was calculated by converting the inspired volume from ATPD to BTPS, adjusting the inspired helium concentration for the dead space of the breathing valve $(0.085 \mathrm{l})$, and adjusting the expired alveolar helium concentration by $5 \%$ by scrubbing an estimated $4 \%$ carbon dioxide from the alveolar gas sample before helium analysis and an estimated net $1 \%$ over-reading compensation due to secondary effects such as respiratory quotient and background oxygen concentration. One trained laboratory technician did $93 \%$ of the transfer factor tests.

Spirometric testing was performed before $D$ the transfer test as outlined by the American Thoracic Society; ${ }^{17}$ for this analysis the largest $N$ of at least three FVC values was selected. A venous blood sample was drawn before the $\stackrel{N}{N}$ transfer test for determination of total $\omega$ haemoglobin and carboxyhaemoglobin concentrations (OSM3 Hemoximeter, Radio- $\stackrel{0}{c}$

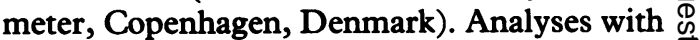
this instrument are based on measurements of the transmission of light through the sample at six wavelengths.

Each subject's height was measured in stock- $\frac{\rho}{\stackrel{\rho}{\rho}}$ ing feet to the nearest centimetre. Weight was $\frac{\varrho}{\sigma}$ measured without shoes and with trousers with empty pockets. The temperature in the exam- $\frac{\delta}{0}$ ination room varied between $20^{\circ} \mathrm{C}$ and $27^{\circ} \mathrm{C} \leftrightharpoons$. $\left(22^{\circ} \mathrm{C}-23^{\circ} \mathrm{C}\right.$ in $90 \%$ of instances). The $\frac{0}{7}$ barometric pressure varied between $722 \%$ $\mathrm{mm} \mathrm{Hg}$ and $777 \mathrm{~mm} \mathrm{Hg}$, with a mean (SD) value of 753 (10) $\mathrm{mm} \mathrm{Hg}$. Altogether, $98 \%$ of the tests were performed between 9 am and $2 \mathrm{pm}$. All measurements were taken in a laboratory located $30 \mathrm{~m}$ above sea level. Never 
Table 1 Physical characteristics and transfer factor test variables in 304 asymptomatic never smokers ${ }^{\star}$ aged 18-73 years living in Bergen, Norway, or 11 surrounding municipalities, 1987-88. Figures are mean (SD) values

\begin{tabular}{|c|c|c|c|}
\hline \multirow{11}{*}{$\begin{array}{l}\text { Age (years) } \\
\text { Height (m) } \\
\text { Weight }(\mathrm{kg}) \\
\text { Haemoglobin }(\mathrm{g} / \mathrm{dl}) \\
\text { Carboxyhaemoglobin }(\%) \\
\text { maxFVC }(\mathrm{l}) \\
\text { Mean TLCo (mmol } / \mathrm{min} / \mathrm{kPa}) \\
\text { Mean VA }(\mathrm{l}, \mathrm{BTPS}) \\
\text { Mean Kco (mmol/min } / \mathrm{kPa} / \mathrm{l}) \\
\text { Mean IVC (l BTPS) }\end{array}$} & $\operatorname{Men}(n=119)$ & \multicolumn{2}{|c|}{ Women $(n=185)$} \\
\hline & $37 \cdot 3 \quad(14 \cdot 9)$ & $45 \cdot 7$ & $(16 \cdot 1)$ \\
\hline & $1.792(0.066)$ & $1 \cdot 644$ & $(0.060)$ \\
\hline & $78 \cdot 26 \quad(10.48)$ & $65 \cdot 24$ & $(10 \cdot 84)$ \\
\hline & $15.4 \quad(0.97)$ & $13 \cdot 7$ & $(0.92)$ \\
\hline & $1.06 \quad(0.27)$ & 0.97 & $(0 \cdot 29)$ \\
\hline & $5.377(0.82)$ & 3.595 & $(0.64)$ \\
\hline & $11.655(1.98)$ & $8 \cdot 062$ & $(1.50)$ \\
\hline & $7.547(1.02)$ & $5 \cdot 477$ & $(0.68)$ \\
\hline & $1.552(0.21)$ & $1 \cdot 478$ & $(0 \cdot 24)$ \\
\hline & $5 \cdot 252(0.77)$ & 3.523 & $(0 \cdot 63)$ \\
\hline
\end{tabular}

$\star I V C / \operatorname{maxFVC}>0.9$ in two tests.

FVC-forced vital capacity; TLCo_carbon monoxide transfer factor; VA-alveolar volume; Kco-transfer coefficient; IVC-inspiratory vital capacity.

smokers were defined as subjects who stated on questionnaires both in 1985 and in 1987-8 that they had never smoked daily.

\section{STATISTICS}

Calculations for descriptive statistics and least square estimates for linear regression models were performed with the Statistical Analysis System. ${ }^{19}$ The measurement error was estimated by computing the average standard deviation of the difference between the two recorded measurements of the variable and dividing this value by $\sqrt{2}$.

\section{Results}

The daily quality control test of the spirometer with the 31 syringe yielded a range of expiratory volume readings of $\pm 2 \%$ of the syringe volume and of inspiratory volume readings of $\pm 3.5 \%$ during the 235 test days. No drift in the instrument was observed during the survey. The coefficients of variation (SD divided by the mean volume multiplied by 100 ) for TLCo, Kco, VA, and IVC were $5 \cdot 7 \%, 7 \cdot 5 \%$, $7 \cdot 2 \%$, and $8 \cdot 3 \%$, respectively, for one member of the survey team on repeated measurements during 130 examination days and $7 \cdot 4 \%, 6 \cdot 1 \%$, $4.3 \%$, and $9.5 \%$, respectively, for another team member during 87 examination days.

When the 540 subjects attending the clinic in

Table 2 Measurement error of transfer test variables by sex, age, and height in asymptomatic, never smoking men and women $\star$ aged 18-73 years living in Bergen, Norway, or 11 surrounding municipalities, $1987-88$

\begin{tabular}{|c|c|c|c|c|}
\hline & $\begin{array}{l}\text { No of } \\
\text { subjects }\end{array}$ & $\begin{array}{l}\text { TLCo } \\
(\operatorname{mmol} / \min / \mathrm{kPa})\end{array}$ & $\begin{array}{l}\text { Kco } \\
(\mathrm{mmol} / \mathrm{min} / \mathrm{kPa} / \mathrm{l})\end{array}$ & $\begin{array}{l}V_{A} \\
(l)\end{array}$ \\
\hline $\begin{array}{l}\text { Sex: } \\
\text { Female } \\
\text { Male }\end{array}$ & $\begin{array}{l}185 \\
119\end{array}$ & $\begin{array}{l}0.35 \\
0.57\end{array}$ & $\begin{array}{l}0.059 \\
0.070\end{array}$ & $\begin{array}{l}0 \cdot 132 \\
0 \cdot 177\end{array}$ \\
\hline $\begin{array}{c}\text { Age (years): } \\
18-34 \\
35-54 \\
55-73\end{array}$ & $\begin{array}{r}105 \\
113 \\
\cdot 86\end{array}$ & $\begin{array}{l}0.47 \\
0.46 \\
0.39\end{array}$ & $\begin{array}{l}0.065 \\
0.061 \\
0.062\end{array}$ & $\begin{array}{l}0 \cdot 130 \\
0 \cdot 175 \\
0 \cdot 143\end{array}$ \\
\hline $\begin{array}{l}\text { Height (m): } \\
\quad<1.64 \\
1.65-1.74 \\
\geqslant 1.75\end{array}$ & $\begin{array}{r}90 \\
119 \\
95\end{array}$ & $\begin{array}{l}0.30 \\
0.44 \\
0.56\end{array}$ & $\begin{array}{l}0.055 \\
0.070 \\
0.064\end{array}$ & $\begin{array}{l}0 \cdot 139 \\
0 \cdot 134 \\
0 \cdot 181\end{array}$ \\
\hline Total & 304 & 0.45 & 0.064 & $0 \cdot 151$ \\
\hline
\end{tabular}

$\star$ IVC/maxFVC $>0.9$ in both trials.

Abbreviations as in table 1 .
1987-8 were again questioned regarding their smoking habits it was found that 16 subjects had taken up smoking and that 14 had been smokers at the time of the 1985 postal survey but had since stopped smoking. On clinical examination by a physician five subjects had clinical signs of chronic obstructive lung disease and two had mucus hypersecretion (chronic bronchitis). Fifteen subjects had a disease that may affect pulmonary function (pulmonary infiltrate (one), upper airway disease (three), heart failure (three), and other disease including muscular and skeletal abnormalities (eight)). Eight subjects were not willing and two were not able to do at least two Tlco measurements. Thirty subjects examined in the first 18 days used an alveolar sample bag with a leak, and the data for these subjects were excluded from the survey. Thus 448 subjects had two TLco recordings. Of these, 304 subjects completed two transfer factor tests with an IVC of $>0.9$ maxFVC (reference population), 76 subjects completed one transfer factor test with an IVC of $>0.9$ maxFVC, and 68 subjects completed two transfer factor tests with IVC of $<0.9$ maxFVC.

Table 1 gives the mean (SD) values for demographic variables, blood haemoglobin and carboxyhaemoglobin concentrations, maxFVC, and the transfer factor variables in the reference population of 119 men and 185 women. For each subject the average of the two measurements of the transfer factor variables is given. The men were an average of eight years younger than the women; all other values were higher for men than for women. The average IVC/FVC ratio was 0.98 for both men and women.

A measure of variability, measurement error defined as the standard deviation of the difference divided by $\sqrt{2}$ (table 2 ) did not differ significantly for men and women and did not change with age; there was a trend for TLCo to increase with height. The measurement errors of values expressed as a percentage of the common mean for TLCO, KCO, and VA, respectively, were $4.3 \%, 4.0 \%$, and $2 \cdot 4 \%$ for women and $4.9 \%, 4.5 \%$, and $2.3 \%$ for men. The average within subject differences between the highest value and the mean value for TLCO, VA, and $\mathrm{KCO}$, respectively, were $0.18 \mathrm{mmol} / \mathrm{min} /$ $\mathrm{kPa}, 0.065 \mathrm{l}$, and $0.031 \mathrm{mmol} / \mathrm{min} / \mathrm{kPa} / \mathrm{l}$ for women and $0.31 \mathrm{mmol} / \mathrm{min} / \mathrm{kPa}, 0.097 \mathrm{l}$, and $0.035 \mathrm{mmol} / \mathrm{min} / \mathrm{kPa} / 1$ for men.

The figure shows the distribution of TLCO, Kco, and VA by age for men and women. TLCO and Kco decreased with increasing age. For men and women there was a strong relation between TLco and both height and age (table 3 ), and the regression coefficients for these variables explained about $48 \%$ of the variance. The analyses for Kco showed that age was a significant regression coefficient in both genders, while height was significant only in men. The proportion of variance explained by height and age, used in the regression equation for TLCo and KCO, did not differ between men and women. VA was dependent on height in both sexes (more strongly in men) but did not 
Distribution of carbon monoxide transfer factor (TLCO), transfer coefficient (KCO), and alveolar volume $(V A)$ by age (years) in never smoking men and women.

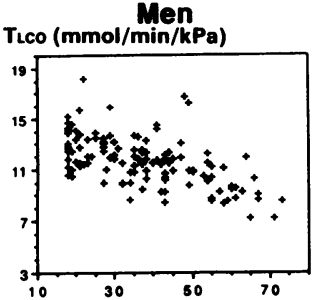

Women

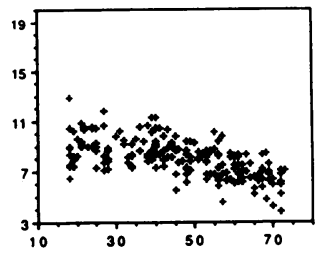

$\mathrm{Kco}(\mathrm{mmol} / \mathrm{min} / \mathrm{kPa} / \mathrm{l})$
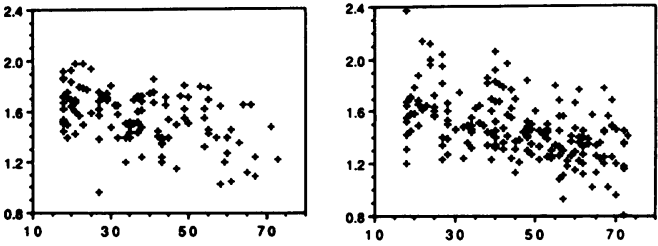

VA (I)
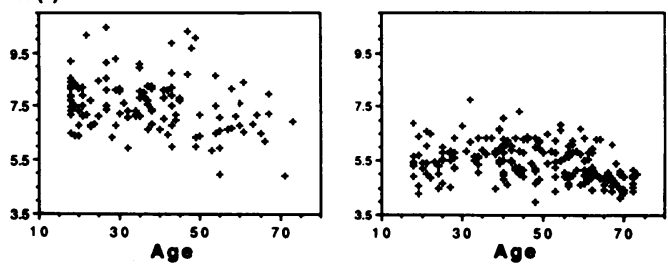

decrease significantly with age. No associations between transfer test variables and weight were observed.

The distribution of TLCO, Kco, and VA expressed as a percentage of predicted values was close to Gaussian by using these regression coefficients. The five percentile values were 79 , 78 , and 86 in men and 82,81 , and 84 in women, respectively. The 95 th percentile values were 124,127 , and 118 in men and 124,120 , and 118 , respectively, in women.

Haemoglobin and carboxyhaemoglobin concentrations were included in a multiple regression analysis of TLCO and KCO in addition to height and age (table 4). The two new independent variables had a significant effect on prediction of $\mathrm{KCO}$ and increased the variance by $7 \%$ $8 \%$ above that explained by age and height. Haemoglobin accounted for about 3\% and carboxyhaemoglobin for an additional $4 \%$. In never smokers Kco decreased by $13 \%$ in women and by $11 \%$ in men per $1 \%$ increase in carboxyhaemoglobin concentration. (Among 37 asymptomatic smokers Kco decreased by about $2 \%, \mathrm{p}=0.37$.) The residual standard error for an estimate of Kco was $0.18 \mathrm{mmol} /$ $\mathrm{min} / \mathrm{kPa} / \mathrm{l}$ in men and $0.20 \mathrm{mmol} / \mathrm{min} / \mathrm{kPa} / \mathrm{l}$ in women. Haemoglobin and carboxyhaemoglobin concentration were of borderline significance for TLCO in women but not significant in men. A multiple regression analysis of KCO with height, age, haemoglobin and carboxyhaemoglobin concentrations, and gender as covariates did not yield a significant coefficient for gender $(p=0.84)$.

\section{Discussion}

The subjects examined in this survey should be representative of the asymptomatic never smoking general population of the south-western coast of Norway. The response rates in the two phases of the survey were $90 \%$, and $82 \%$, respectively, and neither the non-respondents in the first phase nor the non-attenders in the second phase differed from the respondents and the attenders, respectively, with respect to demographic variables or work/insurance history. As the population of Iceland, Denmark, Sweden, and Norway is homogeneous in terms of ethnic origin, environmental factors, and lifestyle our observations should be representative for the population of north-west Europe.

The survey was planned and the fieldwork started before the recommendations of the American Thoracic Society on Thco measurements were published in $1987 . .^{14}{ }^{15} \mathrm{Our}$ measurements deviated from these recommendations in that we did not require agreement of two TLco measurements within $10 \%$ or $3 \mathrm{ml}$, VA corrected for anatomic dead space, or exclusion of subjects with breath holding time outside nine and 11 seconds. The reproducibility of variables from transfer tests applied under field conditions has not been reported for population surveys, ${ }^{10-12}$ even if two measurements were available. The coefficient of variation observed in the present survey is, however, comparable with what has been observed under laboratory conditions. ${ }^{813}$ About $10 \%$ of the women and $15 \%$ of the men in our population had two TLCo measurements that differed by more than $10 \%$. The inspired volume of the test gas was reduced by the dead space of the apparatus but not by the additional $150 \mathrm{ml}$ of anatomic dead space recommended by the American Thoracic Society. This additional $150 \mathrm{ml}$ would reduce the inspired volume to the alveolar space by $3 \%$ in men and $4 \%$ in women of our survey population. In none of the previous population surveys has the

Table 3 Multiple regressions of mean transfer test variables on age and height by sex in asymptomatic never smokers aged 18-73 years living on the south western coast of Norway, 1987-88

\begin{tabular}{|c|c|c|c|c|c|c|c|}
\hline & \multicolumn{5}{|c|}{ Regression coefficients } & \multirow{2}{*}{$\begin{array}{l}\text { Residual } \\
\text { standard } \\
\text { error }\end{array}$} & \multirow{2}{*}{$\begin{array}{l}\text { Multiple } \\
R\end{array}$} \\
\hline & Constant & Height (m) & p Value & Age (years) & p Value & & \\
\hline $\begin{array}{l}\text { Women } \\
\text { TLco (mmol/min/kPa) } \\
\text { Kco (mmol/min/kPa/l (BTPS) } \\
\text { VA }(1, \text { BTPS) }\end{array}$ & $\begin{array}{l}-4.93 \\
2 \cdot 09 \\
-6.650\end{array}$ & $\begin{array}{c}9 \cdot 11 \\
-0 \cdot 17 \\
7 \cdot 376\end{array}$ & $\begin{aligned}< & 0.001 \\
& 0.56 \\
< & 0.001\end{aligned}$ & $\begin{array}{l}-0.043 \\
-0.008\end{array}$ & $\begin{array}{l}<0.001 \\
<0.001\end{array}$ & $\begin{array}{l}1 \cdot 09 \\
0 \cdot 21 \\
0 \cdot 55\end{array}$ & $\begin{array}{l}0.479 \\
0 \cdot 242 \\
0 \cdot 412\end{array}$ \\
\hline $\begin{array}{l}\text { Men } \\
\text { TLco (mmol/min/kPa) } \\
\text { Kco (mmol/min/kPa/l (BTPS) } \\
\text { VA }(1, \text { BTPS) }\end{array}$ & $\begin{array}{r}-8.05 \\
3.04 \\
-12.31\end{array}$ & $\begin{array}{c}12 \cdot 17 \\
-0.67 \\
11 \cdot 078\end{array}$ & $\begin{array}{c}<0.001 \\
<0.05 \\
0.001\end{array}$ & $\begin{array}{l}-0.057 \\
-0.008\end{array}$ & $\begin{array}{l}<0.001 \\
<0.001\end{array}$ & $\begin{array}{l}1.44 \\
0.18 \\
0.70\end{array}$ & $\begin{array}{l}0.476 \\
0.245 \\
0.519\end{array}$ \\
\hline
\end{tabular}

Abbreviations as in table 1 . 
Table 4 Multiple regression of TLCo and KCO on height, age, and haemoglobin and carboxyhaemoglobin concentrations in asymptomatic never smokers aged 18-73 years living in south western coast of Norway, 1987-88

\begin{tabular}{|c|c|c|c|c|c|c|c|c|}
\hline & \multicolumn{4}{|c|}{$\operatorname{Men}(n=119)$} & \multicolumn{4}{|c|}{ Women $(n=185)$} \\
\hline & \multicolumn{2}{|c|}{$T L C O(\operatorname{mmol} / \min / k P a)$} & \multicolumn{2}{|c|}{$\mathrm{KCO}(\operatorname{mmol} / \min / \mathrm{kPa} / \mathrm{l})$} & \multicolumn{2}{|c|}{$T L C O(\mathrm{mmol} / \mathrm{min} / \mathrm{kPa})$} & \multicolumn{2}{|c|}{$\mathrm{KCO}(\mathrm{mmol} / \min \mid \mathrm{kPa} / \mathrm{l})$} \\
\hline & & p Value & & p Value & & p Value & & p Value \\
\hline \multirow{2}{*}{$\begin{array}{l}\text { Intercept } \\
\text { Height (m) } \\
\text { Age (years) } \\
\text { Haemoglobin (g/dl) } \\
\text { Carboxyhaemoglobin } \\
\quad(\%)\end{array}$} & $\begin{array}{r}-10.92 \\
12.33 \\
-0.056 \\
0.185\end{array}$ & $\begin{array}{c}<0.05 \\
<0.001 \\
<0.001 \\
0.19\end{array}$ & $\begin{array}{r}2.66 \\
-0.71 \\
-0.008 \\
0.041\end{array}$ & $\begin{array}{l}<0.001 \\
<0.01 \\
<0.001 \\
<0.05\end{array}$ & $\begin{array}{r}-7 \cdot 81 \\
9 \cdot 41 \\
-0.047 \\
0.223\end{array}$ & $\begin{array}{c}<0.01 \\
<0.001 \\
<0.001 \\
\\
0.05\end{array}$ & $\begin{array}{r}1.35 \\
-0.05 \\
-0.008 \\
0.057\end{array}$ & $\begin{array}{r}<0.01 \\
0.86 \\
<0.001 \\
<0.001\end{array}$ \\
\hline & -0.273 & 0.59 & $-0 \cdot 167$ & $<0.01$ & -0.534 & 0.05 & -0.193 & $<0.001$ \\
\hline
\end{tabular}

anatomic dead space been deducted from the inspired volume. ${ }^{10-12}$ Our experience is that use of the above criteria for an acceptable test will give few tests with results with breath holding times outside nine and 11 seconds. The percentage of subjects or tests excluded because of an inability to have a breath holding time within nine and 11 seconds has not been reported. ${ }^{14}$

The 304 subjects used to develop the present prediction model had an IVC/FVC ratio $>0.9$ in both tests. The 76 subjects with only one IVC/FVC $>0.9$ had a mean (SD) TLCo and Kco of $102 \%(13 \%)$ and $104 \%$ (14\%) of predicted from the present model, respectively; and the 68 subjects with both IVC/FVC $<0.9$ had a mean (SD) TLCo and Kco of $97 \%$ (11\%) and $101 \%(12 \%)$ of the predicted values, respectively. The rigid criterion of IVC/FVC $>0.9$ does not seem to be critical if the other criterion are achieved for an acceptable test. Our findings are a confirmation of observations made by Knudson et al in 463 asymptomatic never smokers. ${ }^{12}$

TLCo and Kco in the present population showed little decline before the middle of the fourth decade of life (figure). The age regression was in crude agreement with what has been previously observed in selected samples of non-smoking men in Belgium ${ }^{7}$ and Finland ${ }^{8}$ and of non-smoking women in Finland. ${ }^{8}$ The sex specific age regression coefficients of TLCO and Kco vary twofold (table 5) among the three previous reported population surveys and the present survey of non-smokers. ${ }^{10-12}$ The negative age regression is largest in the model from Tucson, Arizona ${ }^{12}$; this may be the case partly because the model used included only men $\geqslant 25$ years old and women $\geqslant 20$ years old while the three other models of multiple linear regression included subjects $\geqslant 18$ years of age. The age regression for Kco was higher in men than in women except in the Norwegian survey, where no difference was found between genders. In the Norwegian population of never smokers the age decline of height standardised $\mathrm{FEV}_{1}$ was the same in men and women.

In the three populations previously surveyed $^{10-12}$ and in the present population the height regression for TLCO was always greater in men than in women, but the sex specific coefficient varied twofold to threefold among the surveys (table 5). The height coefficient for Kco was negative in all surveys but not significantly different from null for men in Italy and for women in Norway. The European summary equation did not include height for prediction of $\mathrm{KCO}^{13}$

The population surveys show that the height regression coefficient for $\mathrm{VA}$ is higher in men than in women, probably because of anthropometric differences between the genders. Among the previous population surveys, the regression coefficient on height in the models varied by $45 \%$ in men and $29 \%$ in women, being largest for the Norwegian population. Age was not significant in any survey.

The method of Crapo and Gardner was applied to compare the results of the transfer test in our 304 reference subjects with results predicted from models developed for the populations of Helsinki, Finland ${ }^{8}$; Po, Italy ${ }^{11}$; the European community ${ }^{13}$; the state of

Table 5 Regression coefficients of transfer test variables on age and height in previous community studies of never smokers and in European Community for Coal and Steel summary equations

\begin{tabular}{|c|c|c|c|c|c|c|}
\hline & \multicolumn{2}{|c|}{$T L C O(\operatorname{mmol} / \min / \mathrm{kPa})$} & \multicolumn{2}{|c|}{$\mathrm{KCO}(\mathrm{mmol} / \mathrm{min} / \mathrm{kPa} / \mathrm{l})$} & \multicolumn{2}{|l|}{$V A(l)$} \\
\hline & Height (m) & Age (years) & Height (m) & Age (years) & Height (m) & Age (years) \\
\hline \multicolumn{7}{|l|}{ Men: } \\
\hline Michigan, USA $^{10}$ & $5 \cdot 51$ & -0.077 & -0.75 & -0.010 & $7 \cdot 60$ & \multirow{6}{*}{-0.018} \\
\hline Po, Italy ${ }^{11}$ & $14 \cdot 76$ & -0.065 & -0.04 & -0.023 & 9.90 & \\
\hline Tucson, USA ${ }^{12}$ & 11.89 & -0.092 & -0.79 & -0.042 & $8 \cdot 84$ & \\
\hline European Community for & & & & & & \\
\hline Coal and Steel ${ }^{13}$ & $11 \cdot 11$ & -0.066 & & -0.011 & & \\
\hline Present study & $12 \cdot 17$ & -0.057 & $-0 \cdot 67$ & -0.008 & $11 \cdot 08$ & \\
\hline \multicolumn{7}{|l|}{ Women: } \\
\hline Michigan, USA ${ }^{10}$ & $5 \cdot 36$ & -0.037 & -0.61 & -0.005 & $6 \cdot 46$ & \multirow{6}{*}{-0.005} \\
\hline Po, Italy ${ }^{11}$ & $15 \cdot 69$ & -0.068 & -0.84 & -0.017 & $5 \cdot 73$ & \\
\hline Tucson, USA ${ }^{12}$ & 6.27 & -0.048 & -0.93 & -0.025 & $7 \cdot 10$ & \\
\hline European Community for & & & & & & \\
\hline Coal and Steel ${ }^{13}$ & $8 \cdot 18$ & -0.049 & & -0.004 & & \\
\hline Present study & $9 \cdot 11$ & -0.043 & $-0 \cdot 17$ & -0.008 & $7 \cdot 38$ & \\
\hline
\end{tabular}


Michigan ${ }^{10}$; and Tucson, Arizona. ${ }^{12}$ The mean of the residuals for TLCo values obtained with the models from Helsinki, Michigan, and the European community was $<0.67 \mathrm{mmol} / \mathrm{min} /$ $\mathrm{kPa}$, which was the limit set by Crapo and Gardner $^{21}$ of reference regression equations that could be applied in our population. The observations in our asymptomatic never smokers are mostly in agreement with what was predicted from the model of the reference population of Michigan. The predicted values from the models from Po and Tucson, however, were considerably higher, probably because of methodological differences. The breath holding time measured by the method of the Epidemiology Standardisation Project ${ }^{22}$ was applied in these two surveys and gave a TLco value $7 \%$ larger $^{23}$ than that found by the method of Jones and Meade. ${ }^{18}$ Furthermore, the dead space of the instrument was not deducted from the inspiratory volume in the two latter studies. The use of the largest TLCO value, as in the study by Paoletti et al, ${ }^{11}$ instead of the average of two values would in the present study give a $2 \%$ higher result.

The values for alveolar volume adjusted TLCO (KCO) in the Norwegian population were about $4 \%$ lower in women and $6 \%$ lower in men than those observed in the population of Michigan $^{10}$ and were considerably lower than those observed in studies in Italy and Arizona. The subjects of both genders in the present study were about $5 \mathrm{~cm}$ taller than the adult population of Michigan and almost $8 \mathrm{~cm}$ taller than the adult Italian population. Tall subjects may have lower Kco values than shorter subjects because of poorer perfusion in the apex of the lungs in the erect position. A decrease in KCO with growth and increasing height has been shown in children and adolescents. ${ }^{24}$ Our observations should be confirmed in other populations with the same height as the present population. While mean TLCo, Kco, and VA values differed considerably by the various linear prediction models, only minor differences were observed in the SD of residuals (observed-predicted).

In patients who have anaemia or polycythemia, or who receive a blood transfusion but have healthy lungs, TLCO changes by about $7 \%$ with a change in haemoglobin concentration of $1 \mathrm{~g} / \mathrm{dl}^{25}$ In the population study in Arizona packed cell volume was measured in $71 \%$ of 228 healthy reference subjects. ${ }^{12}$ The investigators found a significant increase of $\mathrm{T}_{L C O}$ and KCO of approximately $1.7 \%$ per percentage increase in packed cell volume in women only. In our survey all reference subjects except one man had haemoglobin concentration measured. The observed range (maximum minimum) of haemoglobin concentrations was $66 \mathrm{~g} / 1$ in men and $61 \mathrm{~g} / 1$ in women. Values for TLCO in women and for KCO in both women and men increased by approximately $2 \%$ per $10 \mathrm{~g} / 1$ for this range of haemoglobin concentration.

Carboxyhaemoglobin concentration was measured in all subjects except one man (table 1 ), and the range of values was up to $1.4 \%$ in women and $1.6 \%$ in men. These concentra- tions, as well as the gender related differences in concentration among never smokers in Norway, are in agreement with previous observations in a large population of nonsmoking blood donors in St Louis, Missouri. ${ }^{26}$ The variation among subjects may be due to differences in concentration of carbon monoxide in the inspired air, endogenous carbon monoxide production, and exercise level. A multiple linear regression which included height, age, and haemoglobin concentration showed that the decrease in TLCo with increasing carboxyhaemoglobin concentration was of borderline significance in women and was not significant in men (table 4). The regression coefficient, however, reflected a magnitude of $3 \%$ decrease in TLCO per $1 \%$ change in carboxyhaemoglobin concentration. This decrease is more than that observed in experimental studies, where small amounts of carbon monoxide were added in four subjects ${ }^{7}$ or in 10 subjects when repeated transfer tests were done which caused an increasing carboxyhaemoglobin concentration. ${ }^{27}$ Leech et al found that the magnitude of the back pressure in 177 non-smoking subjects reduced the TLCo by approximately $0.6 \%$ of the baseline value for a $1 \%$ increase in carboxyhaemoglobin concentration. ${ }^{23}$ Several approximations were used for this estimation, as the concentration was calculated from the oxygen rebreathing procedure. $^{28}$

Carboxyhaemoglobin concentration explains a much larger fraction of the Kco variation than of the TLCo variation. The reduction in $\mathrm{Kco}$ is due to two effects of carboxyhaemoglobin. The first is a reduction of the carbon monoxide driving pressure across the alveolar membrane because of the carbon monoxide back pressure in the lung capillaries. The second is the reduction of available haemoglobin binding sites. Our findings indicate that $\mathrm{KCO}$ is more sensitive to changes in carboxyhaemoglobin concentration in never smokers than in smokers. This finding, taken with the existing data in the published work on asymptomatic smokers with higher baseline carboxyhaemoglobin concentration indicate that its effect on $\mathrm{KCO}$ is non-linear from $0.5 \%$ to approximately $5.0 \%$. Its effects on Kco have not, to our knowledge, been reported previously among never smokers and should be examined in other populations.

In summary, the reference equations and normal limits for the transfer test variables described were derived from a healthy never smoking segment of a randomly selected population on the south-western coast of Norway. The measurement of haemoglobin and carboxyhaemoglobin concentrations is important for interpretation of both individual and group estimates of $\mathrm{Kco}$ and should be performed whenever possible.

We thank Lene Svendsen and Bjorg Meidell for technical help during the survey, Valborg Baste for preparing the database for analyses, and Albert Liou for assistance with programming.

The study was supported by grants from the Royal Norwegian Council for Scientific and Industrial Research, the Norwegian Research Council for Science and the Humanities, the Norwegian Asthma and Allergy Association, and the Research Fund Glaxo, Norway A/S. 
1 Ogilvie CM, Forster FE, Blakemore WS, Morton JW. standardised breath holding technique for the clinical measurement of the diffusing capacity of the lung fo carbon monoxide. J Clin Invest 1957;36:1-17.

2 Thurlbeck WM. Chronic airflow obstruction in lung disease. Philadelphia: WB Saunders, 1976:378.

3 Tukiainen P, Taskinen E, Holsti P, Korhola O, Valle $M$. Prognosis of cryptogenic fibrosing alveolitis. Thorax 1983 38:349-55.

4 Herbert SJ, Weill H, Stuckey WJ, Uner C, Gonzales E, Ziskind MN. Pulmonary diffusing capacity in polycythemic states before and after phlebotomy. Chest 1965 48:408-15.

5 Lipscomb DJ, Patel K, Hughes JMB. Interpretation of increase in the transfer coefficient for carbon monoxide (TLCo/VA or KCO). Thorax 1978;33:728-33.

6 Teculescu DB, Stanescu DC. Lung diffusing capacity. Normal values in male smokers and non-smokers usin the breath-holding technique. Scandinavian Journal of Respiratory Diseases 1970;51:137-49.

7 Frans A, Stanescu DC, Veriter C, Clerbaux T, Brasseur L. Smoking and pulmonary diffusing capacity. Scandinavian
Journal of Respiratory Diseases 1975;56:165-83.

8 Salorinne Y. Single-breath pulmonary diffusing capacity. Scandinavian Journal of Respiratory Diseases 1976; supp 96:1-84.

9 Viljanen A. Reference values for spirometric, pulmonary diffusing capacity and body plethysmographic studies. difusing capacity and body plethysmograph

10 Miller A, Thornton JC, Warshaw R, Anderson H, Teirstein AS, Selikoff IJ. Single-breath diffusing capacity in a representative sample of the population of Michigan, a large industrial state. Predicted values, lower limits of normal, and frequencies of abnormality of smoking history. Am Rev Respir Dis 1983;127:270-7.

11 Paoletti P, Viegi G, Pistelli G, et al. Reference equations for single-breath diffusing capacity. A cross-sectional analysis and effect of body size and age. Am Rev Respir Dis 1985; 132:806-13.

12 Knudson RJ, Kaltenborn WT, Knudson DE, Burrows B. The single-breath carbon monoxide diffusing capacity. Reference equations derived from a healthy nonsmoking population and effects of hematocrit. Am Rev Respir Dis 1987;135:805-11.

13 Quanjer PH. Standardized lung function testing. Bull Eur Physiopathol Respir 1983;19(suppl 5):39-44.
14 Crapo RO, Gardner RM, Clausen JL, et al. Single-breath carbon monoxide diffusing capacity (transfer factor). Recommendations for standard technique. Am Rev Respir Dis 1987;136:1299-307.

15 Gardner RM, Crapo RO, Teculescu DB. Standardization of spirometry and single-breath TLco tests. Eur Respir $J$ 1988;1:293-6.

16 Nelson SB, Gardner RM, Crapo RO, Jensen RL. Performance evaluation of contemporary spirometers. Chest 1990;97:288-97.

17 American Thoracic Society. Snowbird workshop on standardization of spirometry. Am Rev Respir Dis 1979; 119:831-8.

18 Jones RS, Meade F. A theoretical and experimental analysis of anomalities in the estimation of pulmonary diffusing capacity by the single-breath method. $Q J$ Exp Physiol capacity by the

19 SAS Institute. SAS/STAT user's guide: statistics. 6th ed. Cary, North Carolina: SAS Institute, 1988:773-876.

20 Bakke P, Gulsvik A, Lilleng P, Overa O, Hanoa R, Eide GE. Postal survey on airborne occupational exposures and respiratory disorders in Norway. Causes and consequences on non-responders. J Epidemiol Community quences on non-resp
Health 1990;44:316-20.

21 Crapo RO, Gardner RM. TLco reference equations: a perspective. Am Rev Respir Dis 1986;134:856.

22 Ferris BG. Epidemiology standardization project. Am Rev Respir Dis 1978;118(suppl):62-72.

23 Leech JA, Martz L, Liben A, Becklake MR. Diffusing capacity for carbon monoxide. The effects of different derivations of breathhold time and alveolar volume and of carbon monoxide back pressure on calculated results. $\mathrm{Am}$ Rev Respir Dis 1985;132:1127-9.

24 O'Brodovich HM, Mellins RB, Mansell A. Effects of growth on the diffusion constant for carbon monoxide. Am Rev Respir Dis 1982;125:670-3.

25 Bates DV. Respiratory function in disease. Philadelphia: WB Saunders, 1989:356.

26 Kahn A, Rutledge RB, Davis GL, et al. Carboxyhemoglobin sources in the metropolitan St Louis population. Arch Environ Health 1974;29:127-35.

27 Frey TM, Crapo RO, Jensen RL, Elliott CG. Diurnal variation of the diffusing capacity of the lung: is it real? $\mathrm{Am}$ Rev Respir Dis 1987;136:1381-4.

28 Henderson M, Apthorp GH. Rapid method for estimation of carbon monoxide in blood. BMJ 1960;ii:1853-4. 